\title{
ATRIBUT PEMIMPIN IDEAL DAN KEPUTUSAN PARTISIPASI: STUDI ULAYAT DAN ANALISIS POHON KEPUTUSAN
}

\section{Tabah Aris Nurjaman}

Fakultas Psikologi, Universitas Teknologi Yogyakarta, Jl. Siliwangi (Ringroad Utara), Jombor, Sleman, Yogyakarta 55285, Indonesia

Korespondensi: tabah.aris@staff.uty.ac.id

\section{THE ATTRIBUTES OF AN IDEAL LEADER AND PEOPLE'S DECISIONS IN VOTING PARTICIPATION: INDIGENOUS STUDY AND DECISION TREE ANALYSIS}

\begin{abstract}
This study aimed to explore the attributes of an ideal leader and to predict voting participation in the 2019 Indonesian presidential election based on the ideal leader attributes, gender, level of trust, and information processing. The exploration phase was conducted by using an indigenous psychological approach. The prediction phase was conducted by implementing machine learning with a decision tree model. Data was collected at one time by involving 211 respondents ( 53 male, 158 female; $M_{\text {age }}=20.09 ; S D=1.81$ ). Based on the exploration phase, an ideal leader showed seven psychological attributes: personality, integrity, folk-oriented, capability, assertiveness, productivity, and intellectuality. Based on the decision tree model, the trust level was the most dominant factor to predict decision to participate (vote/abstain), followed by the ideal leader attributes. The model showed four categories of participants who were certain to decide to vote in the presidential election, and could predict voting decision (vote/abstain) accurately.
\end{abstract}

Manuscript type: Original Research

Article history:

Received 9 April 2020

Received in revised form 12 April 2020

Accepted 29 May 2020

Available online 15 August 2020

\section{Keywords:}

decision tree model

ideal leader attributes

information processing

participative decision-making

trust level

\begin{abstract}
Abstrak
Penelitian ini bertujuan untuk mengeksplorasi atribut pemimpin ideal dan memprediksi keputusan partisipasi (mencoblos/golput) pada Pemilihan Presiden (Pilpres) 2019 berdasarkan atribut pemimpin ideal, jenis kelamin, tingkat kepercayaan, dan pemrosesan informasi. Tahap eksplorasi atribut pemimpin ideal dilakukan dengan menggunakan pendekatan psikologi ulayat. Tahap prediksi keputusan partisipasi (mencoblos/golput) dilakukan dengan implementasi machine learning model pohon keputusan. Pengambilan data dilakukan dalam satu waktu dengan melibatkan 211 responden (53 pria, 158 wanita; $M_{u s i a}=20.09 ; S D=1.81$ ) Berdasarkan hasil eksplorasi, pemimpin ideal menunjukkan tujuh atribut psikologis yang diurutkan sebagai berikut: personalitas, integritas, orientasi rakyat, kapabilitas, asertivitas, produktivitas, dan intelektualitas. Berdasarkan model pohon keputusan, keputusan partisipasi (mencoblos/golput) paling dominan diprediksi oleh tingkat kepercayaan dan diikuti oleh atribut pemimpin ideal. Model menunjukkan empat kategori partisipan yang dipastikan mengambil keputusan mencoblos di pemilihan presiden dan dapat memprediksi keputusan partisipasi (mencoblos/golput) secara akurat.
\end{abstract}

Kata Kunci: atribut pemimpin ideal, keputusan partisipasi, model pohon keputusan, pemrosesan informasi, tingkat kepercayaan

\section{Dampak dan Implikasi dalam Konteks Ulayat}

Identifikasi dan eksplorasi atribut pemimpin ideal memiliki implikasi penting, khususnya untuk calon pemimpin nasional, para politisi, dan pemangku kebijakan dalam upaya meningkatkan kredibilitas pemimpin di Indonesia. Sejauh ini, tidak begitu banyak media yang menjembatani antara kebutuhan dan harapan psikologis masyarakat tentang figur pemimpin ideal dengan perilaku para pemimpin. Kegagalan pemimpin dalam memetakan kebutuhan masyarakat juga dapat berdampak pada ketidakpercayaan terhadap pemimpin maupun pemerintah. Dengan demikian, perlu ada kesesuaian antara atribut pemimpin yang diharapkan oleh masyarakat dengan para pemimpin skala nasional, sehingga sumber kepuasan psikologis dan kepercayaan masyarakat tidak hanya didasarkan pada kebijakan, melainkan juga dari model perilaku yang ditunjukkan oleh para pemimpinnya. 


\section{PENDAHULUAN}

Angka golongan putih (golput) pada Pemilihan Presiden (Pilpres) di Indonesia relatif besar. Hal ini didasarkan pada angka pemilih terdaftar yang tidak menggunakan hak pilihnya, yaitu sebesar 7.01\% pada Pemilihan Umum (Pemilu) tahun 1999, 15.93\% pada Pemilu tahun 2004, 29.01\% pada Pemilu tahun 2009, dan 25.34\% pada Pemilu tahun 2014 (Surbakti, 2019). Meskipun terjadi penurunan pada Pemilu tahun 2014, angka golput di Pilpres 2014 masih dinilai dominan karena mencapai sekitar 46 juta (Husein, 2014). Secara historis, golput di Indonesia mulai populer di era tujuh puluhan yang diakibatkan oleh ketidakpuasan terhadap pelaksanaan pemilu tahun 1971 yang oleh suatu kalangan akademisi dianggap sebagai ajang penipuan sistematis terhadap rakyat (Yanuarti, 2009). Lebih lanjut, Yanuarti (2009) menjelaskan bahwa perilaku golput dapat dimanifestasikan dengan: 1). tidak hadir di tempat pemilihan umum (TPU) sebagai aksi protes; 2). hadir di TPU tetapi tidak menggunakan hak pilih; 3). menggunakan hak pilih dengan menusuk bagian putih kartu suara; dan 4). tidak terdaftar sehingga tidak punya hak suara.

Pada khazanah psikologi politik, salah satu hal yang menentukan keputusan partisipasi untuk mencoblos atau golput adalah tingkat kepercayaan (Blankenship \& Stewart, 2019; Grönlund \& Setälä, 2007). Di samping itu, pengaruh kepercayaan terhadap partisipasi Pemilu tidak hanya terjadi pada satu wilayah tertentu saja, melainkan bersifat global, baik di Amerika (Blankenship \& Stewart, 2019), Eropa (Allen, 2017), Afrika (Nwankwo, Okafor, \& Asuoha, 2017), maupun Asia (Subanda, 2009). Hal ini mengindikasikan bahwa kepercayaan secara konsisten menentukan keputusan partisipasi masyarakat lintas generasi dan lintas kultural. Pada konteks ini, kepercayaan bersifat generik, baik dalam bentuk kepercayaan terhadap lembaga pemerintah (Lee \& Schachter, 2019), kepercayaan terhadap institusi publik (Andersson \& Lindvall, 2018), kepercayaan terhadap media (Blankenship \& Stewart, 2019), kepercayaan politik (Voogd, Meer, \& Brug, 2019), maupun kepercayaan terhadap orang lain secara umum (Allen, 2017). Tingkat kepercayaan ini dapat dilatarbelakangi oleh berbagai faktor, di antaranya tingkat integritas, faktor internal, situasional, dan kompetensi (Agung, Masyhuri, \& Hidayat, 2013).

Tidak hanya kepercayaan yang secara empiris menentukan keputusan partisipasi antara mencoblos atau golput, tetapi juga pemrosesan informasi (heuristik versus sistematik). Hal ini terbukti secara empiris bahwa pengambilan keputusan dalam pemungutan suara dapat ditentukan oleh pemrosesan informasi heuristik yang ditunjukkan dengan mengambil keputusan berdasarkan pada kesukaan terhadap kandidat tertentu dan mengabaikan informasi kandidat lain (Scheuerman, 
Harman, Mattei, \& Venable, 2017). Namun demikian, hal ini juga bergantung pada keadaan emosi dan wawasan pengetahuan personal individu. Individu dalam kondisi ketakutan menunjukkan pemrosesan sistematis yang lebih besar dengan menghabiskan lebih banyak waktu mencari informasi melalui situs website daripada individu dalam kondisi kemarahan (Parker \& Isbell, 2010). Demikian halnya ditinjau dari wawasan pengetahuan, pemilih yang berpengetahuan rendah cenderung secara heuristik akan menjadikan penampilan kandidat sebagai dasar informasi, sedangkan pemilih yang berpengetahuan tinggi cenderung lebih kebal terhadap pengaruh ini (Ahler, Citrin, Dougal, \& Lenz, 2017). Di samping itu, pemrosesan informasi antara heuristik dan sistematik dalam pemilihan umum juga dapat ditentukan oleh tampilan informasi berbasis teknologi (Katz, Alvarez, Calvo, Escolar, \& Pomares, 2011) ataupun jenis kelamin kandidat (Ditonto, Hamilton, \& Redlawsk, 2013).

Berdasarkan teori pemrosesan informasi, Chaiken dan Ledgerwood (2012) menjelaskan perbedaan model heuristik dan sistematik. Model heuristik lebih berfokus pada isyarat yang menonjol, lebih efisien, dan relatif otomatis, sedangkan model sistematis melibatkan upaya memahami informasi melalui perhatian yang cermat, pemikiran yang mendalam, dan penalaran yang intensif. Sederhananya, apakah individu melakukan upaya kognitif dengan mencari informasi sebelum mengambil keputusan (sistematik) atau tidak (heuristik). Di Indonesia, pencarian informasi pada pemilih generasi milenial didominasi oleh kepentingan masing-masing individu yang didasari oleh aspek psikologis, aspek lingkungan, dan jejaring sosial yang dibangunnya melalui media online (Bakhtiyar, 2018). Pemanfaatan jejaring sosial sebagai sumber informasi tidak hanya menjadi manifestasi dari pemrosesan model sistematik, melainkan juga dapat meningkatkan ketertarikan generasi milenial terhadap politik (Tarsidi, Nugraha, Fadhilah, \& Pertiwi, 2019).

Faktor potensial lainnya yang juga berperan dalam menentukan keputusan partisipasi ialah karakteristik pemimpin. Kepemimpinan secara psikologis dapat dijelaskan oleh sejumlah teori, salah satunya adalah trait theory, misalnya berupa kepercayaan dan intelegensi pemimpin (Nichols \& Cottrell, 2014). Sejauh ini, terdapat sejumlah analisis dan riset yang mengidentifikasi pemimpin nasional ideal di Indonesia, baik dari perspektif psikologi (Chrisharyanto, Rahmania, \& Kertamuda, 2014), politik (Siswanto, 2014), agama (Najib, 2013), maupun komparasi historis (Supriyadi, 2018). Pada skala nasional seperti presiden, karakteristik pemimpin menjadi lebih generik yang dapat merangkul diversitas golongan. Secara politik, pemimpin nasional yang ideal dimanifestasikan melalui kemampuan dalam diplomasi global-regional, pemetaan kepentingan nasional-global, dan manajemen keseimbangan kepentingan (Siswanto, 2014). Secara psikologis, 
pemimpin nasional yang ideal menekankan pada kecerdasan emosional dan kecerdasan spiritual daripada kecerdasan kognitif yang dapat dimanifestasikan dalam bentuk ketegasan, peduli, amanah, ataupun kejujuran (Chrisharyanto, Rahmania, \& Kertamuda, 2014). Namun demikian, karakteristik pemimpin nasional ideal tidak cukup berhenti pada tataran eksplorasi, melainkan juga perlu mengalkulasi dampaknya (misalnya) terhadap keputusan partisipasi pemilih.

Berdasarkan diskusi teoretis yang didukung beberapa bukti empiris lainnya, penelitian ini bertujuan untuk mengeksplorasi atribut pemimpin ideal. Hal ini dilakukan sebagai upaya mengonstruksi pemimpin ideal skala nasional secara kontinuitas. Berbeda dari penelitian sebelumnya, penelitian ini tidak berhenti pada tahap eksplorasi, melainkan juga bermaksud menjadikan hasil studi eksplorasi atribut pemimpin ideal sebagai prediktor terhadap keputusan partisipasi pada Pilpres 2019. Dengan demikian, penelitian ini juga bertujuan untuk membuat model prediksi keputusan partisipasi antara mencoblos atau golput berdasarkan atribut pemimpin ideal, jenis kelamin, tingkat kepercayaan, dan pemrosesan informasi.

\section{METODE}

\section{Partisipan}

Responden penelitian merupakan mahasiswa di Yogyakarta dan memiliki hak suara di pemilihan presiden. Jumlah responden yang memenuhi kriteria dan mengisi kuesioner berjumlah 211 orang yang terdiri dari 53 pria dan 158 wanita $\left(M_{u s i a}=20.09 ; S D=1.81\right)$. Mayoritas responden (90.5\%) merupakan calon partisipan pada pemilihan presiden untuk pengalaman pertamanya.

\section{Desain}

Penelitian dilakukan dengan menggunakan metode kualitatif pendekatan psikologi ulayat yang digunakan untuk mengeksplorasi atribut pemimpin ideal. Penelitian ini juga mengimplementasikan machine learning model pohon keputusan untuk memprediksi keputusan partisipasi (mencoblos/golput).

\section{Prosedur}

Data penelitian ini terdiri dari data kualitatif yang diperoleh dari pertanyaan terbuka dan data kuantitatif yang diperoleh dari kuesioner. Pengumpulan data dilakukan sebelum penyelenggaraan pemilihan presiden, yaitu pada tanggal 12-16 April 2019. Kuesioner kualitatif dan 
kuantitatif diisi oleh responden secara online melalui formulir Google. Data kualitatif diperoleh dengan menggunakan instrumen satu pertanyaan terbuka: "Menurut Anda, bagaimana karakteristik pemimpin ideal bagi Indonesia untuk saat ini?". Adapun, data kuantitatif yang berupa tingkat kepercayaan dan pemrosesan informasi diperoleh dengan menggunakan kuesioner yang masingmasing terdiri dari tiga pertanyaan dengan pilihan jawaban dikotomi. Kuesioner kepercayaan umum diadaptasi dari tiga butir kepercayaan Inter-University Consortium for Political and Social Research (ICPSR) di Universitas Michigan yang pertama kali digunakan pada Pemilu Amerika tahun 1964. Sementara kuesioner pemrosesan informasi terdiri dari tiga pertanyaan: "Apakah Anda mencari tahu informasi diri Capres?", “Apakah Anda mencari tahu latar belakang Capres?”, dan "Apakah Anda mencari tahu visi misi Capres?". Adapun data keputusan partisipasi diperoleh dari satu pertanyaan tentang rencana responden dalam Pilpres 2019 dengan pilihan jawaban dikotomi: "Pada Pemilihan Presiden 2019, saya telah mengambil keputusan untuk ...?” (mencoblos/golput).

\section{Teknik Analisis}

Pada tahap eksplorasi, data kualitatif dianalisis dengan teknik analisis isi, di antaranya open coding, axial coding, dan selective coding (Faturochman, Minza, \& Nurjaman, 2017). Pada tahap prediksi, data interval kepercayaan dan pemrosesan informasi yang berada pada rentang 0 hingga 3 ditransformasi menjadi data nominal, yaitu tingkat kepercayaan (rendah $<1.5<$ tinggi) dan pemrosesan informasi (heuristik $<1.5<$ sistematik). Data nominal tingkat kepercayaan, pemrosesan informasi, jenis kelamin (pria/wanita), dan atribut pemimpin ideal (hasil analisis tahap eksplorasi) digunakan untuk memprediksi keputusan partisipasi (mencoblos/golput). Model prediksi tersebut dikonstruksi dengan konfigurasi $75 \%$ data training (pelatihan) dan $25 \%$ data testing (pengujian) yang dilakukan dengan menggunakan perangkat lunak KNIME versi 4.1.2.

\section{ANALISIS DAN HASIL}

Pada tahap eksplorasi, jawaban responden berupa kalimat deskriptif. Analisis isi dilakukan dengan mengidentifikasi kalimat pertama, sementara kalimat selanjutnya diabaikan. Hasil olah data terdiri dari 99 kata kunci open coding, 32 subtema axial coding, dan 7 tema selective coding. Berdasarkan open coding, diperoleh 99 kata kunci yang merepresentasikan kesamaan makna. Pada proses axial coding, kata kunci tersebut dikategorikan dalam subtema dan diperoleh sebanyak 32 subtema. Pada tahap selective coding, hasil axial coding dikategorikan berdasarkan kesamaan makna ke dalam tujuh tema utama yang merepresentasikan atribut pemimpin ideal. 
Tabel 1 menyajikan persentase ketujuh atribut pemimpin ideal beserta aspek-aspeknya (subtema axial coding). Berdasarkan Tabel 1, terdapat tiga atribut pemimpin ideal paling dominan, yaitu personalitas, integritas, dan orientasi rakyat. Adapun kapabilitas, asertivitas, produktivitas, dan intelektualitas merupakan atribut psikologis yang kurang dominan. Atribut personalitas merepresentasikan tiga aspek psikologis utama, yaitu tegas, adil, dan religius. Atribut integritas ditunjukkan dengan pemimpin yang jujur, bertanggung jawab, dan menepati janji-janji yang dikampanyekan. Atribut pemimpin orientasi rakyat berfokus pada kepentingan rakyat, mengayomi, dan memahami kebutuhan rakyat. Atribut kapabilitas mengindikasikan kemampuan pemimpin untuk memajukan Indonesia, menuntaskan masalah skala nasional, dan menyatukan rakyat dengan segenap kebhinekaannya (diversitas). Asertivitas dimanifestasikan melalui pemimpin yang peduli, ramah, sederhana, dan memiliki toleransi terhadap perbedaan maupun perubahan. Atribut produktif berfokus pada pencapaian target yang dibuktikan dengan kerja nyata dan tidak banyak mengumbar janji. Adapun, intelektualitas mengindikasikan pemimpin yang berwawasan luas dan cerdas.

Tahap prediksi dilakukan dengan menggunakan machine learning model pohon keputusan. Model pohon keputusan dibuat dengan konfigurasi $75 \%$ data untuk pelatihan (training) dan $25 \%$ data untuk pengujian (testing). Model ini digunakan untuk memprediksi keputusan partisipasi antara mencoblos atau golput berdasarkan ketujuh atribut pemimpin ideal, jenis kelamin (pria/wanita), tingkat kepercayaan (rendah/tinggi), dan pemrosesan informasi (heuristik/sistematik). Gambar 1 menunjukkan bahwa tingkat kepercayaan menjadi faktor utama dalam menentukan individu untuk berpartisipasi dalam Pilpres. Meskipun jumlah ( $n$ ) keputusan mencoblos pada kategori kepercayaan rendah $(n=88)$ lebih tinggi daripada kategori kepercayaan tinggi $(n=35)$, tetapi kategori kepercayaan tinggi justru memiliki persentase keputusan mencoblos lebih baik (85.4\%).

Faktor paling berpengaruh berikutnya adalah atribut pemimpin ideal, baik pada kategori kepercayaan tinggi maupun rendah. Kategori kepercayaan rendah dengan atribut pemimpin ideal yang berupa integritas, orientasi rakyat, dan personalitas ditentukan juga oleh faktor pemrosesan informasi. Walaupun demikian, tidak semua responden dengan kepercayaan rendah yang mengaksentuasikan atribut personalitas ditentukan oleh faktor pemrosesan informasi, melainkan hanya terjadi pada jenis kelamin wanita. Ditinjau dari tingkat akurasi maksimal (100\%), terdapat empat kategori yang berdasarkan model dipastikan akan mencoblos pada Pilpres, yaitu: 1). partisipan dengan kepercayaan tinggi yang mengedepankan aspek produktivitas; 2). partisipan dengan kepercayaan tinggi yang mengedepankan aspek asertivitas pemimpin; 3). partisipan dengan 
kepercayaan rendah yang mengidealkan aspek intelektualitas pemimpin; dan 4). partisipan wanita dengan kepercayaan rendah yang mengutamakan aspek personalitas pemimpin, tetapi cenderung mencoblos salah satu calon presiden secara heuristik.

Tabel 1.

Hasil Akhir Kategorisasi Tema

\begin{tabular}{|c|c|c|c|}
\hline Atribut Pemimpin Ideal & Aspek & Jumlah & Persentase \\
\hline \multirow{11}{*}{ PERSONALITAS } & Tegas & 31 & $14.69 \%$ \\
\hline & Adil & 16 & $7.58 \%$ \\
\hline & Religius & 7 & $3.32 \%$ \\
\hline & Berjiwa muda & 3 & $1.42 \%$ \\
\hline & Berwibawa & 3 & $1.42 \%$ \\
\hline & Bijaksana & 3 & $1.42 \%$ \\
\hline & Berjiwa pemimpin & 2 & $0.95 \%$ \\
\hline & Demokratis & 2 & $0.95 \%$ \\
\hline & Berani & 2 & $0.95 \%$ \\
\hline & Visioner & 2 & $0.95 \%$ \\
\hline & Total & 71 & $33.65 \%$ \\
\hline \multirow{5}{*}{ INTEGRITAS } & Jujur & 20 & $9.48 \%$ \\
\hline & Tanggung jawab & 14 & $6.64 \%$ \\
\hline & Menepati janji & 12 & $5.69 \%$ \\
\hline & Tidak korupsi & 2 & $0.95 \%$ \\
\hline & Total & 48 & $22.75 \%$ \\
\hline \multirow{5}{*}{ ORIENTASI RAKYAT } & Merakyat & 19 & $9.00 \%$ \\
\hline & Mengayomi & 11 & $5.21 \%$ \\
\hline & Memahami rakyat & 4 & $1.90 \%$ \\
\hline & Dekat dengan rakyat & 3 & $1.42 \%$ \\
\hline & Total & 37 & $17.54 \%$ \\
\hline \multirow{7}{*}{ KAPABILITAS } & Mampu memajukan Indonesia & 9 & $4.27 \%$ \\
\hline & Mampu menuntaskan masalah & 6 & $2.84 \%$ \\
\hline & Mampu menyatukan Indonesia & 3 & $1.42 \%$ \\
\hline & Memimpin dengan baik & 3 & $1.42 \%$ \\
\hline & Mampu memberantas korupsi & 2 & $0.95 \%$ \\
\hline & Mampu mempertahankan eksistensi negara & 2 & $0.95 \%$ \\
\hline & Total & 25 & $11.85 \%$ \\
\hline \multirow{5}{*}{ ASERTIVITAS } & Peduli & 5 & $2.37 \%$ \\
\hline & Ramah & 2 & $0.95 \%$ \\
\hline & Sederhana & 2 & $0.95 \%$ \\
\hline & Toleran & 2 & $0.95 \%$ \\
\hline & Total & 11 & $5.21 \%$ \\
\hline \multirow{3}{*}{ PRODUKTIVITAS } & Kerja nyata & 7 & $3.32 \%$ \\
\hline & Tidak banyak janji & 3 & $1.42 \%$ \\
\hline & Total & 10 & $4.74 \%$ \\
\hline \multirow{3}{*}{ INTELEKTUALITAS } & Berwawasan luas & 7 & $3.32 \%$ \\
\hline & Cerdas & 2 & $0.95 \%$ \\
\hline & Total & 9 & $4.27 \%$ \\
\hline TOTAL A & UT PEMIMPIN IDEAL & 211 & $100.00 \%$ \\
\hline
\end{tabular}




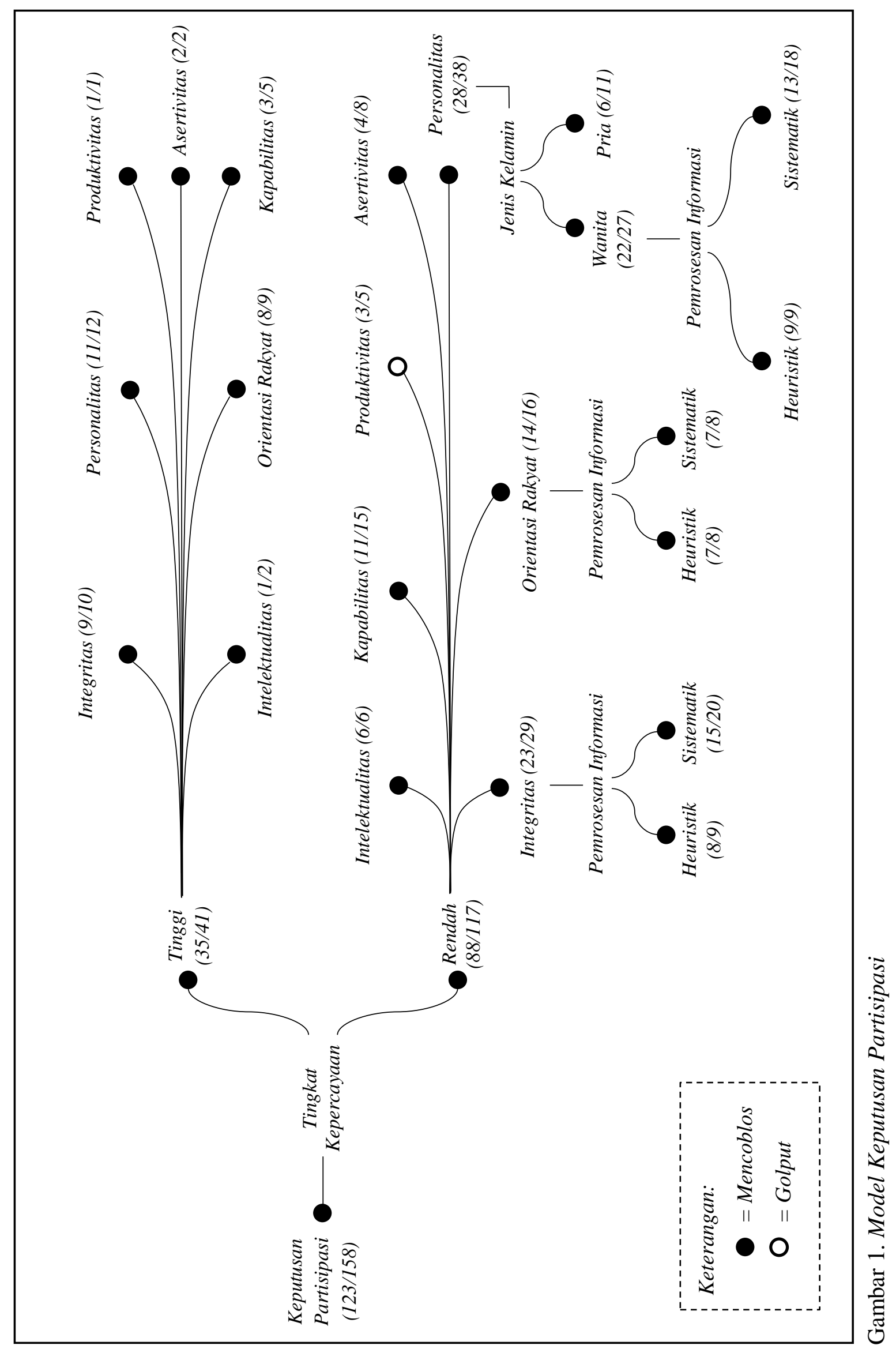


Pengujian (testing) terhadap model pohon keputusan dilakukan untuk melihat derajat ketepatan dan kesalahan klasifikasi dari keputusan partisipasi (mencoblos/golput) antara data observasi dan data prediksi. Berdasarkan hasil pengujian ini, model pohon keputusan dapat memprediksi keputusan partisipasi dengan tingkat akurasi sebesar 88.679\% $(\kappa=.193)$. Hasil pengujian menunjukkan 47 ketepatan klasifikasi dan enam kesalahan klasifikasi keputusan partisipasi antara data observasi dengan data prediksi. Berdasarkan identifikasi lanjutan pengujian model, keputusan mencoblos didominasi oleh jenis kelamin wanita dengan tingkat kepercayaan rendah, cenderung sistematik dalam mengambil keputusan, serta menekankan atribut personalitas sebagai pemimpin ideal. Adapun, keputusan golput didominasi oleh jenis kelamin wanita dengan tingkat kepercayaan rendah, cenderung mengambil keputusan secara heuristik, serta mengaksentuasikan produktivitas sebagai atribut pemimpin ideal.

\section{DISKUSI}

Melalui pendekatan ulayat, penelitian menemukan bahwa pemimpin ideal memiliki tujuh atribut psikologis, yaitu personalitas, integritas, orientasi rakyat, kapabilitas, asertivitas, produktivitas, dan intelektualitas. Atribut pemimpin ideal berupa personalitas, integritas, orientasi rakyat, asertivitas, dan intelektualitas merupakan kualitas personal psikologis yang berartimasyarakat memimpikan pemimpin yang adekuat, baik secara kognitif yang meliputi wawasan, afektif (seperti peduli), dan perilaku yang dapat ditunjukkan melalui banyak hal, seperti tegas dan jujur. Northouse (2016) menjelaskan lima fondasi utama kepemimpinan model sifat, yaitu: 1). intelegensi, artinya pemimpin cenderung memiliki tingkat intelegensi lebih tinggi daripada bukan pemimpin; 2). kepercayaan diri akan memastikan kompetensi dan kemampuan seorang pemimpin; 3). determinasi, artinya merepresentasikan hasrat pemimpin untuk menuntaskan suatu tugas atau permasalahan yang dihadapi; 4). integritas, artinya menunjukkan seorang pemimpin yang jujur dan terpercaya; dan 5). sosiabilitas, artinya pemimpin berfokus pada kepuasan relasional dengan individu lain termasuk bawahannya. Adapun, aspek pemimpin ideal yang berupa ketegasan $(14.69 \%)$, peduli $(2.37 \%)$, jujur (9.48\%), cerdas $(.95 \%)$, dan integritas $(22.75 \%)$ sejalan dengan penelitian Chrisharyanto dkk. (2014) yang juga menemukan aspek-aspek tersebut dengan ketegasan sebagai aspek dominan dari pemimpin nasional ideal. Supriyadi (2018) juga mengajukan analisis yang sama secara historis bahwa ketegasan menjadi salah satu karakteristik dari sekurangnya dua presiden Indonesia. 
Penelitian ini juga menemukan bahwa kapabilitas dan produktivitas menjadi atribut pemimpin ideal di Indonesia. Artinya, masyarakat Indonesia mendambakan pemimpin yang memiliki kapasitas yang cukup untuk memajukan Indonesia, menuntaskan masalah skala nasional, menyatukan rakyat dengan segenap kebhinekaannya, serta tetap berfokus pada pembuktian dengan kerja nyata dan bukan hanya sekadar menjual janji. Atribut kapabilitas dan produktivitas cukup penting dimiliki pada seorang pemimpin yang berfokus pada pencapaian tujuan. Menurut Northouse (2016), pemimpin perlu memiliki kemampuan untuk mendefinisikan tujuan, mengklarifikasi langkah-langkahnya, melewati hambatan, dan memberi dukungan kepada bawahan agar menjadi produktif. Namun, produktivitas yang berupa pencapaian tujuan tidak serta merta diperoleh begitu saja, melainkan juga perlu adanya keseimbangan antara perilaku pemimpin (direktif, suportif, partisipatif, atau berorientasi pada prestasi), karakteristik bawahan, dan karakteristik tugas. Sejalan dengan penelitian sebelumnya, Gunawan (2019) menemukan bahwa mayoritas responden mengutamakan perilaku pemimpin yang berorientasi pada prestasi dan direktif daripada yang suportif dan partisipatif. Kemampuan untuk menyatukan Indonesia yang sarat kebhinekaan (1.42\%) sebagai salah satu aspek dari atribut kapabilitas pemimpin ideal sejalan dengan analisis Najib (2013) yang menyatakan bahwa pemimpin ideal Indonesia adalah pemimpin yang mampu menjaga pluralitas Indonesia.

Berdasarkan model pohon keputusan, atribut ulayat pemimpin ideal menentukan keputusan partisipasi antara mencoblos atau golput dengan didahului faktor tingkat kepercayaan sebagai faktor utama, kemudian diikuti pemrosesan informasi dan jenis kelamin. Hasil temuan ini sejalan dengan penelitian-penelitian sebelumnya, meskipun objek kepercayaannya berbeda. Andersson dan Lindvall (2018) membuktikan bahwa peningkatan satu unit kepercayaan pada institusi publik ratarata meningkatkan peluang pemungutan suara sebesar sembilan persen, sedangkan kepercayaan pada institusi swasta tidak memiliki efek yang signifikan. Demikian halnya dengan Lee dan Schachter (2019) yang menyatakan bahwa individu yang memercayai lembaga pemerintah cenderung lebih memilih dan menandatangani petisi. Adapun di Indonesia, Subanda (2009) menjelaskan bahwa salah satu keputusan golput rakyat adalah ketidakpercayaan. Sejalan dengan hasil penelitian ini yang didasarkan pada model pohon keputusan, tingkat kepercayaan rendah mendominasi dan mampu memprediksi keputusan partisipasi lebih jauh daripada tingkat kepercayaan tinggi. Berbeda halnya dengan Allen (2017) yang menjelaskan bahwa ketidakpercayaan terhadap politik tidak memberi dampak yang berbeda antara memilih dan golput, melainkan ditentukan oleh tingkat kepercayaan terhadap orang lain. Hal ini sejalan dengan studi 
Wang (2016) yang mengonfirmasi hubungan tidak langsung antara kepercayaan politik dengan jumlah pemilih.

Model pohon keputusan juga menunjukkan pengaruh pemrosesan informasi (heuristik/sistematik) terhadap keputusan partisipasi (mencoblos/golput) pada responden dengan tingkat kepercayaan rendah yang mengidealkan pemimpin dengan atribut personalitas, integritas, dan orientasi rakyat. Chaiken dan Ledgerwood (2012) menjelaskan bahwa proses kerja mental pada model heuristik jauh lebih sedikit daripada model sistematik, sehingga tidak bergantung pada kemampuan (misalnya, pengetahuan dan waktu yang cukup) untuk berpikir dengan hati-hati. Pada penelitian ini, model heuristik ditunjukkan oleh individu yang tidak mencari informasi diri, latar belakang, dan visi misi Capres, di mana hal ini berlawanan dengan model sistematik. Artinya, individu tidak memiliki informasi yang cukup untuk melakukan perbandingan antara kandidat Capres, sehingga berpotensi mengambil keputusan secara otomatis. Kemudian, Ahler dkk. (2017) juga menemukan bahwa individu dengan tingkat pengetahuan rendah cenderung memilih kandidat tertentu berdasarkan pada penampilan semata. Scheuerman dkk. (2017) juga menemukan hal serupa bahwa keputusan heuristik kerap kali dilakukan individu terhadap kandidat yang disukainya dan mengabaikan informasi pada kandidat lainnya. Kemudian, terdapat pula penelitian Parker dan Isbell (2010) yang mengonfirmasi pengambilan keputusan untuk mencari informasi (model sistematik) ketika dalam kondisi ketakutan daripada ketika sedang marah. Di samping itu, jenis kelamin kandidat juga menentukan pencarian informasi, di mana individu cenderung mencari informasi terhadap kandidat wanita daripada pria, khususnya mencari informasi tentang masalah afeksi (Ditonto dkk., 2013).

Hasil pengujian model pohon keputusan menunjukkan perbedaan faktor yang melatarbelakangi keputusan partisipasi antara mencoblos dan golput. Perbedaan paling dominan terletak pada atribut pemimpin ideal dan pemrosesan informasi. Misalnya, atribut pemimpin ideal berupa produktivitas melatarbelakangi keputusan golput (produktivitas $\rightarrow$ golput), sementara atribut personalitas melatarbelakangi keputusan mencoblos (personalitas $\rightarrow$ mencoblos); demikian halnya pada pemrosesan informasi (heuristik $\rightarrow$ golput; sistematik $\rightarrow$ mencoblos). Apabila dibandingkan, kedua pola pada atribut pemimpin ideal cukup logis dan lebih baik, mengingat atribut personalitas (33.65\%) lebih unggul daripada atribut produktivitas $(4.74 \%)$, sehingga peluang angka prediksi mencoblos lebih besar daripada golput (rasio 7:1). Kemudian, kedua pola pemrosesan informasi dinilai relatif lebih baik daripada jika sebaliknya (misalnya, heuristik $\rightarrow$ mencoblos). Keputusan partisipasi mencoblos berbasis heuristik secara implisit tetap mencederai demokrasi sekaligus 
mengindikasikan rendahnya "melek" politik. Berbeda dengan keputusan golput yang pada awalnya dinilai sebagai wujud ketidakpercayaan (Yanuarti, 2009), mencoblos berbasis heuristik justru secara holistik berdampak masif. Misalnya terpilihnya pemimpin yang unggul dari perspektif penampilan fisik, tetapi tidak memiliki kecukupan atribut-atribut psikologis yang dibutuhkan. Apabila situasi semacam ini terjadi, tentunya akan merugikan rakyat sendiri karena pemimpin tidak adekuat. Toor dan Ogunlana (2009) menjelaskan bahwa atribut negatif pemimpin (misalnya, kekuasaan yang disalahgunakan, komunikasi buruk, dan rendahnya pengalaman) berdampak pada performa anggota kelompoknya, sehingga mengurangi efisiensi produktivitas. Terlebih lagi pada konteks kepemimpinan nusantara, Marsetio (2018) menjelaskan pemimpin sebagai penjelmaan delapan dewa (Astrabrata), di antaranya Hyang Surya, Hyang Candra, Hyang Kartika, Hyang Bayu, Hyang Himando, Hyang Brahma, Hyang Baruna, dan Hyang Pratala. Hal ini menegaskan bahwa atribut kepemimpinan yang adekuat mutlak dimiliki pemimpin, khususnya pada skala nasional, seperti Indonesia yang sarat akan kebhinekaan.

\section{SIMPULAN DAN SARAN}

\section{Simpulan}

Penelitian menemukan bahwa personalitas menjadi atribut pemimpin ideal paling dominan daripada enam atribut lainnya. Atribut personalitas merepresentasikan ketegasan, adil, dan religius sebagai tiga aspek utama. Atribut pemimpin ideal lainnya berupa integritas, orientasi rakyat, kapabilitas, asertivitas, produktivitas, dan intelektualitas. Intelektualitas yang ditunjukkan dengan aspek wawasan luas dan kecerdasan menjadi atribut paling rendah dari pemimpin ideal. Berdasarkan model pohon keputusan, tingkat kepercayaan menjadi faktor paling dominan dalam menentukan keputusan partisipasi. Ditinjau dari tingkat akurasinya, terdapat empat kategori yang dapat dipastikan mengambil keputusan mencoblos di Pilpres, yaitu partisipan dengan kepercayaan tinggi yang mengedepankan aspek produktivitas dan asertivitas pemimpin, partisipan dengan kepercayaan rendah yang mengidealkan aspek intelektualitas pemimpin, dan partisipan wanita dengan kepercayaan rendah yang mengutamakan aspek personalitas pemimpin, tetapi cenderung mencoblos salah satu calon presiden secara heuristik. Berdasarkan pengujian model, keputusan partisipasi mencoblos didominasi oleh wanita dengan tingkat kepercayaan rendah, mengambil keputusan secara sistematik, dan menekankan personalitas sebagai atribut pemimpin ideal. 


\section{Saran Teoretis}

Atribut pemimpin ideal skala nasional perlu dieksplorasi lebih luas lagi dengan mempertimbangkan kebhinekaan masyarakat Indonesia. Hasil penelitian yang dilakukan di Yogyakarta ini tidak menjamin akan menghasilkan hal yang sama jika dilakukan dengan kultur dan karakteristik yang berbeda. Dengan demikian, diharapkan penelitian berikutnya dapat melakukan penelitian yang sama dengan konteks kultural yang berbeda atau melakukan penelitian skala besar dengan mempertimbangkan karakteristik masyarakat Indonesia yang bhineka. Adapun model pohon keputusan partisipasi dapat juga dikembangkan dengan implementasi machine learning model lainnya, misalnya Artificial Neural Network (ANN).

\section{Saran Praktis}

Kesesuaian antara atribut pemimpin ideal dan pemimpin Indonesia yang terpilih ditentukan oleh masyarakat sendiri melalui Pemilu. Masyarakat memiliki kebebasan untuk menentukan pemimpin yang diharapkan dan dipercayainya. Bahkan, masyarakat juga memiliki kebebasan untuk ikut andil mengkampanyekan pemimpin pilihannya. Namun sayangnya, ada juga sebagian kecil masyarakat yang tidak mempedulikan atribut pemimpin ideal sehingga mengambil keputusan golput saat Pemilu. Oleh karena itu, diharapkan semua pihak baik para akademisi, praktisi, masyarakat, maupun pemangku kebijakan untuk bergotong-royong meningkatkan kesadaran berbangsa dan bernegara dalam upaya menekan angka golput di Pemilu Indonesia.

\section{REFERENSI}

Agung, I. M., Masyhuri, \& Hidayat. (2013). Dinamika ketidakpercayaan terhadap politisi: Suatu pendekatan psikologi indigenous. Jurnal Psikologi, 9(1), 25-30.

Ahler, D. J., Citrin, J., Dougal, M. C., \& Lenz, G. S. (2017). Face value? Experimental evidence that candidate appearance influences electoral choice. Political Behavior, 39(1), 77-102. doi: 10.1007/s11109-016-9348-6

Allen, T. J. (2017). Exit to the right? Comparing far right voters and abstainers in Western Europe. Electoral Studies, 50, 103-115. doi: 10.1016/j.electstud.2017.09.012

Andersson, G., \& Lindvall, N. (2018). Trust and turnout: An empirical study of South African voters (Research paper). Uppsala University, Sweden.

Bakhtiyar. (2018). Dinamika literasi politik menjelang tahun 2019: Urgensitas memahami perilaku 
pemilih milenial. Jurnal Sosiologi Pendidikan Humanis, 1, 65-72.

Blankenship, B. T., \& Stewart, A. J. (2019). Threat, trust, and Trump: Identity and voting in the 2016 presidential election. Politics, Groups, and Identities, 7(3), 724-736. doi: $10.1080 / 21565503.2019 .1633932$

Chaiken, S., \& Ledgerwood, A. (2012). A theory of heuristic and systematic information processing. Dalam P. Van Lange, A. Kruglanski, \& E. Higgins (Eds.), Theories of social psychology (hlm. 246-266). SAGE Publications.

Chrisharyanto, H., Rahmania, T., \& Kertamuda, F. E. (2014). Konsep pemimpin nasional yang baik: Survey pada masyarakat Jakarta. Jurnal Sosio-Humaniora, 5(1), 1689-1699. doi: 10.1017/CBO9781107415324.004

Ditonto, T. M., Hamilton, A. J., \& Redlawsk, D. P. (2013). Gender stereotypes, information search, and voting behavior in political campaigns. Political Behavior, 36(2), 335-358. doi: 10.1007/s11109-013-9232-6

Faturochman, Minza, W. M., \& Nurjaman, T. A. (2017). Memahami dan mengambangkan indigenous psychology. Pustaka Pelajar.

Grönlund, K., \& Setälä, M. (2007). Political trust, satisfaction and voter turnout. Comparative European Politics, 5(4), 400-422. doi: 10.1057/palgrave.cep.6110113

Gunawan, G. (2019). Model kepemimpinan ideal bagi mahasiswa di Jawa Barat. Journal of Psychological Science and Profession, 3(1), 1-5. doi: 10.24198/jpsp.v3i1.22804

Husein, H. (2014, Mei 19). Bravo 'partai golput.' Republika. https://www.watchindonesia.de/wpcontent/uploads/Teraju19.5.14.pdf

Katz, G., Alvarez, R. M., Calvo, E., Escolar, M., \& Pomares, J. (2011). Assessing the impact of alternative voting technologies on multi-party elections: Design features, heuristic processing and voter choice. Political Behavior, 33(2), 247-270. doi: 10.1007/s11109-0109132-y

Lee, Y., \& Schachter, H. L. (2019). Exploring the relationship between trust in government and citizen participation. International Journal of Public Administration, 42(5), 405-416. doi: 10.1080/01900692.2018.1465956

Marsetio. (2018). Kepemimpinan nusantara. Universitas Pertahanan.

Najib, A. (2013). Konstruksi pemimpin ideal untuk Indonesia. Jurnal Agama Dan Hak Azazi Manusia, 3(1), 141-161.

Nichols, A. L., \& Cottrell, C. A. (2014). What do people desire in their leaders? The role of 
leadership level on trait desirability. Leadership Quarterly, 25(4), 711-729. doi: 10.1016/j.leaqua.2014.04.001

Northouse, P. G. (2016). Leadership: Theory and practice. SAGE Publications.

Nwankwo, C. F., Okafor, U. P., \& Asuoha, G. C. (2017). Principle component analysis of factors determining voter abstention in South Eastern Nigeria. Journal of Pan African Studies, 10(3), 249-273.

Parker, M. T., \& Isbell, L. M. (2010). How I vote depends on how I feel: The differential impact of anger and fear on political information processing. Psychological Science, 21(4), 548-550. doi: $10.1177 / 0956797610364006$

Scheuerman, J., Harman, J. L., Mattei, N., \& Venable, K. B. (2017). Heuristic strategies in uncertain approval voting environments. PsyArXiv. https://arxiv.org/pdf/1905.12104.pdf

Siswanto. (2014). Sosok presiden ideal dan tantangan isu-isu global: Menimbang aspek kepemimpinan Capres pada Pilpres 2014. Jurnal Penelitian Politik, 10(2), 1-13.

Subanda, N. (2009). Analisis kritis terhadap fenomena golput dalam pemilu. Jurnal Konstitusi, $2(1), 60-72$.

Supriyadi, H. (2018). Gaya kepemimpinan presiden Indonesia. Jurnal Agregasi: Aksi Reformasi Government Dalam Demokrasi, 6(2), 139-148. doi: 10.34010/agregasi.v6i2.1136

Surbakti, R. (2019, Januari 8). Peserta pemilu dan partisipasi pemilih. Kompas. https://aipi.or.id/assets/pdf/pdf_file/08012019_PesertaPemiludanPartisipasiPemilih_Ramlan _Surbakti.pdf

Tarsidi, D. Z., Nugraha, I., Fadhilah, F., \& Pertiwi, G. (2019). Orientasi “poligami” (politik generasi milenial) dalam menghadapi pesta demokrasi 2019. Prosiding Seminar Nasional \& Call Paper Psikologi Sosial 2019. Fakultas Pendidikan Psikologi Universitas Negeri Malang. http://fppsi.um.ac.id/wp-content/uploads/2019/07/Deni-Zein.pdf.

Toor, S. U. R., \& Ogunlana, S. (2009). Ineffective leadership: Investigating the negative attributes of leaders and organizational neutralizers. Engineering, Construction and Architectural Management, 16(3), 254-272. doi: 10.1108/09699980910951663

Voogd, R., Van Der Meer, T., \& Van Der Brug, W. (2019). Political trust as a determinant of volatile vote intentions: Separating within-from between-person effects. International Journal of Public Opinion Research, 31(4), 669-693. doi: 10.1093/ijpor/edy029

Wang, C. H. (2016). Political trust, civic duty and voter turnout: The mediation argument. Social Science Journal, 53(3), 291-300. doi: 10.1016/j.soscij.2016.04.008 
Yanuarti, S. (2009). Golput dan pemilu di Indonesia. Jurnal Penelitian Politik, 6(1), 21-32. 